\title{
Analisis Pengaruh Penyaluran Dana Zakat Terhadap Perkembangan Usaha Kecil dan Menengah (UKM) Mustahik
}

\author{
Noor Amelia *, Ines Saraswati Machfiroh *, Yuli Fitriyani * \\ * Politeknik Negeri Tanah Laut \\ Program Studi D-III Akuntansi \\ Jl. A. Yani Km. 06, Desa Panggung, Kalimantan Selatan \\ E-mail: noor.amelia@politala.ac.id \\ E-mail: inessaraswati.m@politala.ac.id \\ E-mail: yulihazami@politala.ac.id
}

\begin{abstract}
Abstrak
Pertumbuhan Usaha Kecil dan Menengah (UKM) merupakan unsur penting untuk meningkatkan sektor ekonomi masyarakat. Mayoritas permasalahan UKM terdapat pada kepemilikan modal. Salah satu solusi permasalahan tersebut melalui kegiatan penyaluran dana Zakat Produktif. Dalam penelitian ini bertujuan untuk menganalisis pengaruh zakat produktif yang disalurkan oleh BAZNAS terhadap perkembangan UKM mustahik. Penelitian ini bersifat kuantitatif dengan teknik pengambilan sampel secara acak berupa data hasil observasi dan pengisian kuesioner kepada 30 orang mustahik yang memperoleh bantuan dana zakat produktif melalui program TALA Makmur BAZNAS kabupaten Tanah Laut. Data tersebut dianalisis dengan menggunakan metode analisis deskriptif agar dapat mengetahui pengaruh adanya pemberian dana zakat produktif kepada para mustahik dengan menggunakan Uji Beda (Paired T-Test). Variabel terkait yaitu; Pendapatan, Modal, dan Keuntungan. Penelitian ini menunjukkan hasil bahwa terdapat pengaruh bantuan modal dari BAZNAS terhadap pengembangan usaha mustahik yang mengakibatkan meningkatnya pendapatan dan keuntungan sesudah memperoleh dana zakat produktif tersebut. Sehingga dengan meningkatnya penyaluran zakat produktif dapat meningkatkan perekonomian khususnya di kecamatan Pelaihari.
\end{abstract}

Kata kunci: UKM, Mustahik, BAZNAS Tala, Zakat Produktif

\begin{abstract}
Growth of Small and Medium Enterprises (SMEs) is an important element to improve the economic sector of society. The majority of SME problems lie in capital ownership. One solution to the problem is through the distribution of Earning Zakat. This study aims to analyze the effect of productive zakat distributed by BAZNAS on the development of SME Mustahik. This research used quantitative method with random sampling techniques in the form of data from observations and filling out questionnaires to 30 Mustahik people who receive productive zakat assistance through the TALA Makmur BAZNAS program in Tanah Laut District. The data were analyzed using descriptive analysis method to determine the effect of giving productive zakat funds to the Mustahik using Paired T-Test. The related variables are capital, income, and profit. The results showed that there was an influence of capital assistance from $B A Z N A S$ on the development of Mustahik businesses which resulted in increased income and profits after obtaining the productive zakat funds. So that the increased distribution of productive zakat could improve the economy, especially in the Pelaihari sub-district.
\end{abstract}

Keywords: SMEs, Mustahik, BAZNAS Tala, Productive Zakat

\section{Pendahuluan}

Pembangunan perekonomian merupakan target penting bagi Indonesia. Salah satu unsur penting untuk meningkatkan sektor ekonomi masyarakat adalah pertumbuhan Usaha Kecil dan Menengah (UKM). 
UKM dapat membuka peluang untuk tenaga pekerja yang memiliki pendidikan rendah dalam pelaksanaan usaha berskala kecil baik secara sederhana maupun secara pemanfaatan teknologi yang modern. Pertumbuhan UKM di Kabupaten Tanah Laut juga menjadi perhatian khusus pemerintah Kabupaten Tanah Laut melalui program unggulan dalam rangka peningkatan Industri Kecil dan Menengah. Mayoritas permasalahan UKM di Kabupaten Tanah Laut terletak pada kepemilikan modal, yang mana pemilik usaha kecil tersebut tidak memiliki modal yang cukup untuk meningkatkan usaha yaang mereka jalankan. Salah satu sektor yang dapat membantu UKM untuk memperoleh dana melalui kegiatan penyaluran Zakat oleh lembaga penghimpun dana zakat.

Indonesia adalah Negara yang mayoritas menganut agama islam yang terbesar di dunia sehingga terdapat potensi sangat besar dalam peranan meningkatkan kegiatan perekonomian Islam melalui adanya program pengelolaan zakat. Pemerintah telah mengeluarkan Undang-Undang Nomor 23 Tahun 2011 tentang pengelolaan zakat khususnya di dalam pasal 3 ayat 2 yang menggambarkan tujuan pengelolaan zakat untuk kesejahteraan masyarakat dan menangani kemiskinan. Zakat memiliki peranan penting dalam mengentaskan kemiskinan secara menyeluruh melalui penyelesaian akar masalahnya. Pada awalnya pendistribusian ZIS bertujuan untuk membantu pihak yang berhak menerima zakat untuk pemenuhan kebutuhan konsumtif saja [1]. Saat ini zakat tidak hanya bersifat konsumtif melainkan juga ditujukan untuk bantuan produktif. Zakat produktif didistribusikan kepada mustahik yang memiliki kendala dalam usahanya, berupa bantuan modal, peralatan, soft skill, dan lain sebagainya. Tujuan pendistribusian zakat produktif ini adalah merubah seorang mustahik atau pihak penerima zakat menjadi seorang muzzaki atau pihak pemberi zakat.

Zakat produktif mulai banyak dikembangkan oleh berbagai lembaga penghimpun zakat sebagai upaya peningkatan pendayagunaan zakat kepada pihak yang membutuhkan. Mustahik yang memiliki kendala dalam mengembangkan usahanya menjadi sasaran pendistribusian zakat ini. Kendala yang banyak dialami oleh para mustahik diantaranya kesulitan dalam memperoleh modal ke berbagai lembaga keuangan seperti bank karena para mustahik khawatir tidak mampu mengembalikan dana tersebut baik dengan bunga maupun tanpa bunga serta kurangnya informasi dan kesulitan dalam meakses pinjaman dana tersebut. Upaya pemerintah dalam pengembangan usaha mikro melalui penyaluran kredit bebas agunan maupun pinjaman dari bank milik pemerintah masih belum dapat dirasakan oleh masyarakat secara merata. Sehingga adanya Badan Amil Zakat ini, diharapkan menjadi salah satu solusi dalam upaya pemerataan bantuan modal yang diberikan kepada para mustahik. Terdapat perbedaan yang signifikan terhadap perkembangan usaha mikro setelah memperolah bantuan modal oleh Rumah Zakat kepada para mustahik [2].

BAZNAS merupakan lembaga penghimpun dan penyalur zakat yang bergerak di bawah pengawasan pemerintah yang tersebar di seluruh Indonesia. Banyak penelitian yang menganalisis adanya peran dana zakat produktif guna perkembangan usaha mikro mustahik. Menurut Alaydrus [3] hasil penelitiannya terhadap BAZDA kota Pasuruan Jawa Timur dengan menyalurkan ZIS secara produktif dapat berpengaruh terhadap kesejahteraan mustahik. Selain itu, sebagian besar mustahik mengalami kemajuan setelah menerima zakat produktif dari BAZNAS Sragen [4].

Badan Amil Zakat Nasional (BAZNAS) Kabupaten Tanah Laut merupakan lembaga pengelola dana zakat di Kabupaten Tanah Laut. Berdasarkan Peraturan BAZNAS Kabupaten Tanah Laut Nomor IV/PR/BAZNAS-TALA/12/2018,

BAZNAS

Kabupaten Tanah Laut merupakan lembaga yang menjalankan fungsi dan tugas BAZNAS di tingkat kabupaten Tanah Laut. BAZNAS Kabupaten Tanah Laut melakukan kegiatan Penghipunan zakat fitrah, zakat mall, zakat infaq, sadaqah, CSR, profesi dan Dana Sosial Keagamaan dari Lembaga/ Badan/Kantor/Instansi Pemerintah, BUMN, Swasta dan perseorangan, melalui Unit Pengumpul Zakat (UPZ), serta dapat secara langsung dari para muzaki/munfik/dermawan, lewat Rekening. Tabel 1 menunjukkan menunjukkan bahwa sejak tahun 2016 hingga 2018 terjadi peningkatan dana zakat, infaq sedekat yang dikumpulkan BAZNAS Tanah Laut.

TABEL I

Total Penghimpunan Dana ZaKat, INFAQ Dan SedeKaH

\begin{tabular}{|c|l|}
\multicolumn{2}{c|}{ BAZNAS TALA } \\
\hline Tahun & \multicolumn{1}{c|}{ Penghimpunan Dana ZIS } \\
\hline 2016 & Rp. 267.023.416,- \\
\hline 2017 & Rp. 1.021.784.206,-- \\
\hline 2018 & Rp.1.088.223.236 \\
\hline
\end{tabular}

BAZNAS Kabupaten Tanah Laut memiliki lima program pengelolaan zakat, diantaranya:

1) TALA CERDAS untuk mustahik yang membutuhkan bantuan pendidikan seperti beasiswa, pendukung kelengkapan pendidikan dan sejenisnya.

2) TALA MAKMUR adalah pendistribusian penyaluran bagi mustahik agar mandiri secara ekonomi: pendampingan dan pelatihan usaha, penambahan modal, modal bergulir dan sejenisnya.

3) TALA SEHAT adalah penyaluran untuk mustahik yang membutuhkan pertolongan kesehatan berupa biaya untuk bantuan berobat, rawat inap dan sejenisnya.

4) TALA PEDULI adalah penyaluran bagi mustahik 
yang membutuhkan bantuan mendesak, dan mengalami musibah berupa kebanjiran, kebakaran, tanah longsor, putting beliung, perbaikan rumah dan sejenisnya.

5) TALA TAQWA adalah penyaluran untuk meningkatkan kuantitas maupun kualitas keagamaan islam yang meliputi insentif guru mengaji dan TPA, kaum masjid, bantuan perbaikan masjid, mushalla dan sebagainya.

Donasi yang diberikan kepada para mustahik yang disalurkan melalui program TALA Makmur merupakan dana zakat yang bersifat produktif. Akan tetapi berdasarkan penelitian sebelumnya belum ada penelitian signifikan yang dilakukan di BAZNAS TALA dengan tujuan yang sama. Selain itu, masih terdapat kendala dalam proses penyaluran dana zakat melalui program TALA Makur ini, dikarenakan masih ada pihak mustahik yang menggunakan bantuan dana tersebut untuk kepentingan yang bersifat konsumtif selain pengembangan usaha. Oleh karena itu, penelitian ini ditujukan untuk menganalisis ada tidaknya pengaruh pemberian dana bantuan zakat produktif oleh BAZNAS Tanah Laut terhadap perkembangan usaha kecil dan menengah para mustahik.

\section{Metode Penelitian}

Penelitian dilakukan dengan metode menganalisa data berdasarkan hasil kuesioner para mustahik sebanyak 30 orang yang memperoleh bantuan dana dari program TALA Makmur, terhadap masalah yang didapatkan. Oleh karena itu, diperoleh gambaran yang jelas mengenai objek yang diteliti dan untuk mengambil kesimpulan. Data yang didapatkan akan diolah dengan menggunakan aplikasi SPSS. Kegiatan penelitian ini menggunakan beberapa variable yang akan di analisis, diantaranya:

a) Modal Usaha Kecil Menengah (UKM)

Modal adalah salah satu sarana yang penting dalam menjalankan usaha. Bentuk modal sangat beragam diantaranya dapat berupa uang, barang, peralatan, gedung, dan lain sebagainya. Modal digunakanuntuk membiayai kegiatan usahanya agar aktivitas tersebut bisa berjalan sesuai yang direncanakan. Kapabilitas Usaha Kecil Menengah tidak lepas dari kebutuhan modal dalam menjalankan usaha untuk memperoleh produk baik berupa barang maupun jasa. Satuan modal yang digunakan untuk mengukur modal usaha (M), dengan beberapa kondisi yang terjadi, diantaranya:

1) Modal UKM mengalami perkembangan apabila jumlah modal UKM tersebut meningkat dibandingkan rata-rata jumlah sebelum maupunsetelaah penyaluran bantuan modal dari BAZNAS Tala (nilai $M$ > rata-rata Modal).

2) Modal UKM mengalami penurunan apabila jumlah modal UKM lebih sedikit dari rata-rata jumlah sebelum dan sesudahpemberian bantuan modal dari BAZNAS Tala (skor $\mathrm{M}<$ rata-rata Modal).

3) Modal UKM dalam kondisi stabil apabila jumlah rata-rata modal UKM sebelum dan setelah pemberian bantuan modal dari BAZNAS Tala sama (skor $\mathrm{M}$ = rata-rata Modal)

b) Bantuan modal dari BAZNAS

Bantuan modal dari BAZNAS berupa uang merupakan penambahmodal usaha yang dimiliki dalam jumlah tertentu dikarenakan salah satu alasan gagalnya UKM mempertahankan usahanya yaitu kekurangan modal untuk menjalankan usahanya. Variabel ini bertujuan untuk mengukur besarnya bantuan modal produktif yang didapat dari para mustahik dari BAZNAS Tala melalui program TALA Makmur.

c) Pendapatan UKM

Total hasil barang maupun jasa yang dapat dijual merupakan pendapatan pengusaha UKM. Perhitungan pendapatan UKMmerupakan hasil kali dari total harga dan kuantitas. Analisis perubahan pendapatan dapat diketahui melaluiada atau tidaknya kenaikan, penurunan atau stabil.

d) Keuntungan/Laba

Laba atau keuntungan adalah meningkatnya pendapatan di atas biaya selama satu periode berjalan. Sedangkan struktur akuntansi menyatakan bahwa labam erupakan selisih perhitungan pendapatan dan biaya. Dalam penelitian ini, perhitungan keuntungan (L) dilakukan dengan cara mengurangkan pendapatan keseluruhan (TR) dalam satu bulan dengan keseluruhan biaya (TC) atau ( $\mathrm{L}=\mathrm{TR}$ - TC) dalam satu bulan. Perubahan Laba dapat diketahui melalui ada atau tidaknya kenaikan, penurunan atau stabil.

\section{Metode Analisis Data}

Metode analisis yang dilakukan dalam penelitian ini adalah metode deskriptif yaitu proses analisis penyaluran dana zakat produktif pihak BAZNAS kota Pelaihari. Kemudian dilanjutkan dengan analisis data secara kuantitatif melalui Uji Validitas dan Uji Reliabilitas terhadap Kuisioner Penelitian. Hasil kuisioner tersebut dianalisi kembali menggunakan metode uji beda atau Uji Paired T-test untuk mengetahui ada tidaknya pengaruh penyaluran dana zakat sebagai bantuan modal usaha terhadap perkembangan usaha mustahik.

\section{Uji Validitas}

Uji valiliditas dilakukan sebagai alat ukur valid atau tidak validnya sebuah kuesioner [5]. Kuesioner yang disebut valid apabila mempunyai pearson correlation kurang dari 0,05 dan muatan faktor lebih besar dari 0,32. Adapun kriteria kevalidan kuesioner dilihat melalui nilai KMO (Kaiser Mayer Olkin), sebagai berikut:

KMO mendekati $1,00=$ sangat baik 
KMO mendekati $0,80=$ baik

KMO mendekati $0,70=$ cukup baik

KMO mendekati $0,60=$ sedang

KMO mendekati $0,50=$ buruk

\section{Uji Realibilitas}

Uji Realibitas merupakan alat ukur kuesioner berdasarkan indikator variabel atau konstruksi menggunakan Uji Reliabilitas. Kuesioner dikatakan handal atau reliable apabila jawaban koresponden terhadap pertanyaan bersifat konsisten [5]. Uji Reliabilitas terhadap kuesioner penelitian dilaksanakan sebelum memulai penelitian dan melakukan uji hipotesis untuk mengetahui sebuah pertanyaan yang sesuai atau yang digunakan dalam sebuah variabel.

Uji reliabilitas dilakukan pada 1 (satu) waktu, dan setelah itu dilakukan perbandingan dengan pertanyaan yang lain/dengan pengukuran korelasi antar dari setiap jawaban. Pada program SPSS, dalam penelitian ini menggunakan metode cronbach alpha, yaitu dimana kuesioner dapat dikatakan handal apabila cronbach alpha mencapai $\geq 0,60$.

\section{Uji Beda atau Paired T-test}

Pengujian berikutnya adalah mengolah data hasil kuesioner menggunakan Uji beda agar dapat menentukan apakah dua sampel yang tidak mempunyai hubungan dengan perbedaan rata-rata. Uji Beda bertujuan untuk menganalisis adanya pengaruh dari penyaluran dana zakat produktif untuk perubahan dari tingkat modal, pendapatan usaha dan keuntungan usaha mustahik yang memperoleh bantuan dari dana zakat tersebut. Untuk dapat mendeskripsikan, maka dilakukan uji beda dari variabel modal, penghasilan serta dari keuntungan usaha yang didapatkan dengan menggunakan uji beda atau paired T-test, berdasarkan dari hipotesis berikut:

H1: untuk rata-rata jumlah modal sebelum dan setelah mendapatkan bantuan dana terdapat perbedaan.

Sehingga yang menjadi acuan dalam pengambilan keputusan adalah sebagai berikut:

Apabila probabilitas dari variabel modal $<0.05$, maka H1 diterima.

$\mathrm{H} 2$ : rata-rata pendapatan sebelum dan sesudah menerima bantuan modal terdapat perbedaan.

Sehingga yang menjadi acuan dalam pengambilan keputusan sebagai berikut:

Apabila probabilitas variabel pendapatan $<0.05$, maka $\mathrm{H} 2$ diterima.

H3: laba rata-rata sebelum dan sesudah menerima bantuan modal terdapat perbedaan.

Sehingga yang menjadi acuan dalam pengambilan keputusan sebagai berikut:

Apabila probabilitas variabel keuntungan $<0.05$, maka H3 diterima.

\section{Analisis Data dan Pembahasan}

Penelitian difokuskan untuk dapat menganalisis adanya pengaruh dari penyaluran dana zakat pada program TALA Makmur, untuk mengetahui pengaruh bantuan modal kepada mustahik terhadap pengembangan usaha mikro milik mustahik. Berdasarkan laporan pendistribusian dana Zakat, Infaq dan Sodaqah Tahun 2018 terdapat 76 mustahik yang memperoleh bantuan modal sebesar Rp. 131.850.000 . Akan tetapi, dalam penelitian ini hanya di ambil 30 sampel mustahik secara acak dengan kategori masih aktif dalam UKM. Mustahik tersebut akan diobservasi dan mengisi kuesioner yang telah di sediakan.

A. Sistem Pendistribusian Zakat Produktif di BAZNAS TALA

BAZNAS Tala menyerahkan bantuan dana zakat produktif kepada mustahik yang telah mengajukan permohonan. Pemberian bantuan modal yang diberikan oleh pihak BAZNAS Tala melalui beberapa tahapan. Proses tersebut diawali dengan proses analisa oleh pihak BAZNAS Tala melalui pemilihan mustahik yang berhak memperoleh dana bantuan. Pada awalnya mustahik penerima bantuan modal berjumlah 76 orang di tahun 2018. Pada saat ini mustahik penerima bantuan dana yang masih aktif dalam menjalankan usahanya sekitar 45 mustahik namun yang di ambil sampel dalam kegiatan penelitian ini hanya 30 orang mustahik yang berdomisili di seluruh wilayah Kabupaten Tanah Laut. Berdasarkan hasil wawancara dengan pengurus BAZNAS Tala, terdapat beberapa mustahik penerima modal yang tidak membutuhkan bantuan modal berupa uang, melainkan hanya memerlukan sarana dalam menjalankan usaha. Hal ini berdasarkan hasil analisis pihak BAZNAS Tala.

Tahapan pemberian bantuan modal kepada mustahik diawali dengan proses pengajuan permohonan bantuan modal kepada pihak BAZNAS Tala, kemudian pihak BAZNAS Tala akan menyeleksi isi proposal yang diajukan dan dilakukan analisa mustahik yang dapat menerima. Mustahik yang telah dipilih wajib untuk mengisi formulir yang telah disediakan. Ada beberapa persyaratan dan prosedur yang harus mustahik lengkapi yaitu

1) pengisian formulir,

2) pengisian formulir terhadap keterangan usaha

3) jenis usaha,

4) kendala usaha,

5) surat keterangan tidak mampu, dan

6) pernyataan komitmen.

Setelah terpenuhi semua kriteria yang ditentukan pihak BAZNAS Tala,langkah berikutnya adalah melakukan survey ke lokasi usaha. Apabila data yang diisi sesuai dengan hasil survey, maka pihak Baznaz Tala akan menetapkan mustahik yang berhak mendapatkan bantuan modal. Proses tidak berakhir hanya pada saat pemberian modal, pihak Baznaz Tala akan melakukan monitoring usaha, untuk melihat perkembanganusaha para mustahik. Proses monitoring 
dilaksanakan melaluikegiatan kunjungan pihak BAZNAS Tala kepada Musahik penerima modal yang dilakukan minimal satu bulan sekali atau sesuai dengan kebutuhan. Mustahik diharuskan membuat buku pencatatan usaha, agar pihak Baznaz Tala dapat memantau kenaikan usaha mustahik yang akan diberitahukan kepada kantor pusat.

Tidak hanya proses monitoring, pihak BAZNAS Tala juga melaksanakan berbagai pembinaan usahamelalui kegiatan pelatihan seperti pelatihan penulisan laporan keuangan sederhana atau pembuatan buku usaha, pelatihan pengembangan kemampuan softsklill maupun hardskill, pelatihan manajemen usaha, bahkandilakukan pula pelatihan peningkatan motivasi usaha. Berdasarkan hasil wawancara dari pengurus BAZNAS Tala, ternyata terdapat permasalahan dalam kegiatan program Tala Makmur baik dari factor internal maupun eksternaldiantaranya akibat pergatian pengurus bagian program menyebabkan terjadinyalosscontrol terhadap usaha mustahik selama beberapa bulan. Selain itu, terdapat beberapa mustahik yang mengalami kesulitan dalam mengembangkan usaha dikarenakan sebagian bantuan modal digunakan untuk pemenuhan konsumtif.

Pengukuran keberhasilan dari program Tala Makmur dapat dilihat dari beberapa indikator diantaranya melalui adanya peningkatan perolehan mustahik dalam rentangwaktu satu tahun setelah pemberian bantuan modal, indikator yang lain dapat dilihat melalui ada tidaknya peningkatan kelengkapan usaha maupun system manajemen usaha pada mustahik. Pihak BAZNAS Tala selalumemantau usaha mustahik untuk memastikan berjalannya usaha dan membantu mengatasi kendala usaha yang dialami oleh para mustahik.

B. Uji Validitas dan Uji Reliabilitas terhadap kuesioner penelitian

Hasil uji validitas Kuesioner penelitian yang digunakan dalam kegiatan penelitian ini di buat berdasarkan 4 variabel, diantaranya:

1) Pendayagunaan dana zakat (a)

Berdasarkan hasil uji validitas untuk variable a yaitu Pendayagunaan dana zakat dimana terdapat empat point pertanyaan dengan hasil valid untuk semua pertanyaan.

2) Peran zakat dalam pemberdayaan masyarakat (b)

Berdasarkan hasil uji validitas untuk variable $b$ yaitu Peran zakat dalam pemberdayaan masyarakat dimana terdapat empat point pertanyaan dengan hasil valid untuk semua pertanyaan.

\section{3) Pendampingan oleh BAZNAS Tala (c)}

Berdasarkan hasil uji validitas untuk variable c yaitu Pendampingan oleh BAZNAS Tala dimana terdapat empat point pertanyaan dengan hasil valid untuk semua pertanyaan,

4) Peningkatan Usaha Kecil Mustahik(d)
Berdasarkan hasil uji validitas untuk variable d yaitu Peningkatan Usaha Kecil Mustahik dimana terdapat empat point pertanyaan dengan hasil valid untuk semua pertanyaan.

Berdasarkan hasil uji reliabilitas menunjukkan bahwa kuesioner penelitian dapat dikatakan handal karena nilai cronbach alpha $\geq 0,60$ yaitu sebesar 0,637 .

\section{Interpretasi Hasil Statistik Uji Paired T-test}

Berdasarkan data yang telah diolah oleh peneliti, tedapat tiga variable utama yang akan di uji yaitu variable modal UKM, pendapatanUKM, dan keuntungan UKM

\section{Variabel Modal UKM}

Berdasarkan Hasil uji beda terhadap variabel modal UKMdengan menggunakan Uji Paired T-test menunjukkan hasil sebagai berikut:

1) Nilai korelasi antara dua buah sample yaitu variable modal UKM sebelum dan sesudah pemberian bantuan modal oleh BAZNAS sebesar 0,925. Nilai menunjukan bahwa terdapat kaitan yang kuat dan positif antara kedua variabel.

2) Sig: tingkat peluamg sebesar 0,000 kurang dari 0,05 . Sehingga dapat diartikan signifikan pada level 0,01 .

3) Berdasarkan Tabel 1 output mengguanakan uji Paired T-test di atas diperoleh hasil sig.(2-tailed) untuk modal UKM sebesar $0,000<0,05$ yang berarti bahwa H1 diterima. Sehingga dinyatakan adanya perbedaan terdapat perbedaan antara modal UKM sesudah menerima bantuan modal, sehingga dapat dikatakan bahwa pemberian bantuan modal usaha memberikan dampat positif yaitu adanya peningkatan modal UKM para mustahik.

TABEL 2

\section{UJI BEDA UNTUK VARIABEL MODAL UKM}
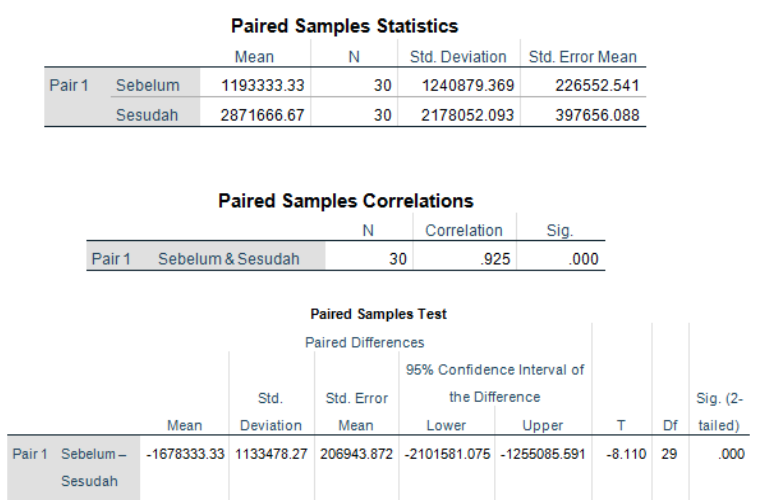

Sumber: Data primer yang diolah, 2018

\section{Variabel Pendapatan UKM}

Berdasarkan Hasil uji beda terhadap variabel pendapatan UKM dengan Uji Paired T-test diperoleh hasil sebagai berikut:

1) Nilai korelasi antara dua buah sample yaitu variable 
pendapatan UKM sebelum dan sesudah pemberian bantuan modal oleh BAZNAS sebesar 0,949. Nilai tersebut menunjukan bahwa terdapat kaitan yang kuat dan positif antara kedua variabel.

2) Sig: tingkat peluang sebesar 0,000 kurang dari 0,05. Hal ini dapat diartikan signifikan pada level 0,01.

3) Berdasarkan Tabel 2 output menggunakan uji Paired T-test di atas diperoleh sig.(2-tailed) untuk pendapatan UKM sebesar $0,000<0,05$ yang berarti bahwa H2 Diterima. Ini berarti bahwa ada perbedaan antara pendapatan UKM sebelum dan sesudah menerima bantuan modal, sehingga dapat dikatakan bahwa pemberian bantuan modal usaha memberikan dampat positif yaitu adanya peningkatan pendapatan UKM para mustahik.

TABEL 3

UJI BEDA UNTUK VARIABEL PENDAPATAN UKM

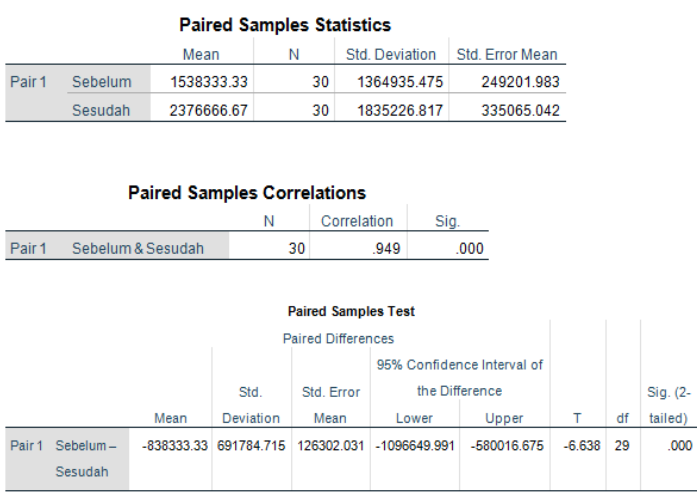

Sumber: Data primer yang diolah, 2018

\section{Variabel Laba Usaha}

Berdasarkan Hasil uji beda terhadap variabel keuntungan/laba UKM dengan melakukan Uji Paired T-test menunjukkan hasil sebagai berikut:

1) Nilai korelasi antara dua buah sample yaitu variable laba UKM sebelum dan sesudah pemberian bantuan modal oleh BAZNAS sebesar 0,960. Nilai menunjukan bahwa terdapat kaitan yang kuat dan positif antara kedua variabel.

2) Sig: tingkat peluang sebesar 0,000 kurang dari 0,05. Hal ini dapat diartikan signifikan pada level 0,01.

3) Berdasarkan Tabel 3 output dari uji Paired T-test di atas diperoleh hasil sig.(2-tailed) untuk laba UKM sebesar $0,000<0,05$ yang berarti bahwa H3 Diterima. Dengan kata lain terdapat perbedaan antara keuntungan/laba UKM sesudah memperoleh bantuan modal, sehingga dapat dikatakan bahwa pemberian bantuan modal usaha memberikan dampat positif yaitu adanya peningkatan keuntungan/laba UKM para mustahik.

TABEL 3

UJI BEDA UNTUK VARIABEL LABA USAHA

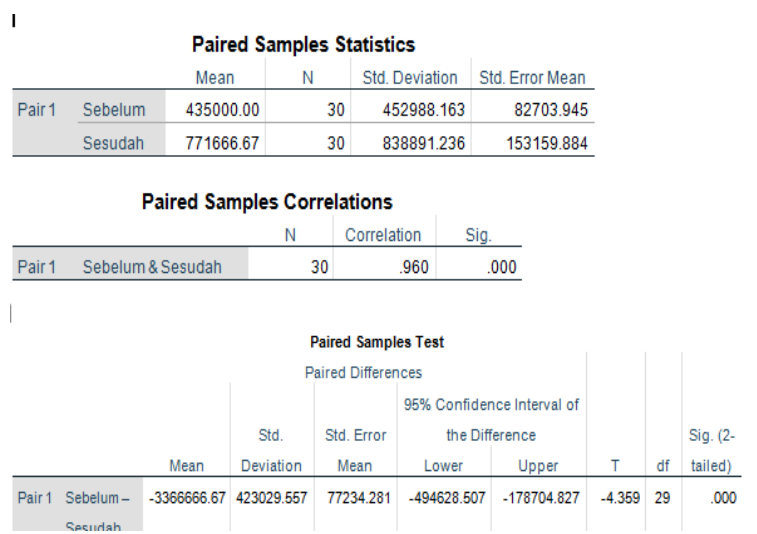

Sumber: Data primer yang diolah, 2018

D. Perubahan Modal, Pendapatan, dan Laba Secara Keseluruhan Setelah dan Sebelum Mendapatkan Bantuan Modal

Pemberian modal melalui dana zakat produktif melalui program TALA Makmur ini memiliki peranan besar bagi UKM yang dijalankan oleh para mustahik. Dengan kata lain dana zakat produktif dapat membantu Mustahik yang mengalami kendala modal. Hal ini disebabkan mustahik tidak adanya keberanian untuk mengajukan pinjaman modal kepada lembaga formal semacam Koperasi, Pegadaian, Bank, dan lembaga pinjaman lainnya dengan berbagai alas an, sepertitakut terlibat riba, takut tidak mampu mengembalikan pinjaman, adanya jaminan/anggunan yang belum tentu dimiliki oleh para mustahik.

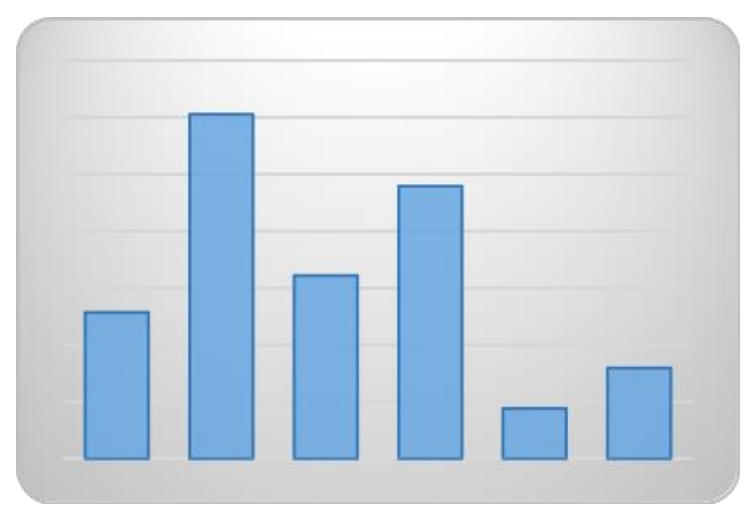

Gambar 1: Rata-rata Modal, Omzet dan Keuntungan Sebelum dan Sesudah adanya Bantuan Dana Zakat Produktif Sumber: Data primer yang diolah, 2018

Perbandingan dari ketiga variabel yaitu modal, pendapatan, dan laba pada gambar 3, menunjukkanadanya pengaruh yang signifikan ketika adanya pemberian bantuan modal yang diberikan oleh pihak BAZNAS Tala diantaranya:

1) Modal UKM para mustahik mengalami kenaikan setelah adanya pemberian bantuan modal oleh BAZNAS Tala. Sebelum adanya pemberian bantuan, modal usaha mikro berkisar antara Rp.500.000 - Rp. 5.000.000 dan setelah mendapatkan bantuan modal dana dari zakat produktif terdapat peningkatan sebesar 2-3 kali lipat jika dibandingkan dengan modal awalnya. 
Sehingga rata-rata modal usaha meningkat sebesar $42 \%$.

2) Sedangkan pendapatan dan laba UKM juga mengalami perkembangan jika dibandingkan dengan sebelum dan sesudah menerima bantuan modal dari BAZNAS Tala. Jika di rata-ratakan pendapatan keseluruhan mustahik mengalami kenaikan sekitar $67 \%$ dan rata-rata laba keseluruhan mustahik juga meningkat sebesar $55 \%$. Akan tetapi pada dasarnya tidak semua UKM yang mengalami kenaikan pendapatan dan laba yang signinifikan. Hal ini dikarenakan terdapat beberapa faktor yang mempengaruhi peningkatan usaha yang dilakukan para mustahik seperti situasi dan kondisi dalam berusaha baik berupa iklim, daya saing, perubahan harga di pasar, dan lain sebagainya.

3) Peningkatan pendapatan yang cukup besar dikarenakan meningkatnya modal usaha sehingga para mustahik dapat meningkatkan produksi yang berdampak pada peningkatkan penghasilan. Adapun Peningkatan labasetidaknya dapat meringankanpara pengusaha UKM dalam meningkatkan perekonomiannya. Walaupun rata-rata peningkatan yang cukup besar, tetapi ada beberapa usaha mustahik mengalami peningkatan maupun penurunan dalam menjalankan usahanya.

Berdasarkan hasil wawancara dengan pihak BAZNAS Tala, pelaksanaan pemberian modal pada program TALA Makmur ini masih terdapat penyalahgunaan bantuan. Bentuk penyalahgunaan oleh beberapa mustahik adalah penggunaan bantuan tersebut bukan untuk menambah modal usaha melainkan sebagai pemenuhan kebutuhan konsumtif dan kesehatan. Hal ini mengakibatkan beberapa usaha yang dilakukan mustahik tersebut mengalami kemunduran, tidak berkembang, bahkan kegagalan usaha. Tetapi meskipun begitu, melalui pembinaan intensif tidak semua mustahik yang berani melakukan penyalahgunaan, sehingga hal ini dapat diatasi, meskipun tidak keseluruhan berhasil ditangani. Melalui bantuan dana untuk tambahan modal, mustahik sangat terbantu dalam mengembangkan usaha yang dimiliki. Hal ini dapat ditunjukkan dari peningkatan modal, kenaikan pendapatan dan laba usaha. Rata-rata ekonomi mustahik juga mengalami perubahan setelah memperoleh bantuan modal. yang disebabkan adanya peningkatan usaha yang mereka miliki. Hingga saat ini, bantuan dana yang diberikan oleh pihak BAZNAS Tala telah berhasil menaikkan standar mustahik menjadi seorang muzakki dan memperbaiki keadaan ekonomi mustahik jauh lebih maju.

\section{Kesimpulan}

Berdasarkan hasil pembahasan tentang ada tidaknya pengaruh penyaluran dana zakat terhadap perkembangan usaha UKM dan pengumpulan data mengenai penelitian, sehingga dapat dinyatakan sebagai berikut:

1) Pengumpulan zakat, BAZNAS Tala menyediakan berbagai sarana kepada para muzakki, dana zakat yang terhimpun semuanya disalurkan pada program Tala Cerdas, Tala Taqwa, Tala Sehat, Tala Peduli dan Tala Makmur. Dalam program Tala Makmur menggunakan dasar pemberian bantuan modal kepada mustahik yang membutuhkan bantuan modal.

2) Dari hasil Uji Paired T-test diketahui modal UKM, pendapatan UKM dan laba usaha mustahik terdapat perbedaan secara signifikan antara sebelum dan setelah menerima bantuan modal usaha dari BAZNAS Tala.

3) Adanya masalah dalam pelaksanaan program Tala Makmur, karena disebabkan adanya beberapa mustahik yang masih melakukan penyalahgunaan berupa penggunaan bantuan modal yang digunakan untuk memenuhi kegiatan ekonomi yang mendesakan . dengan demikian untuk mengubah mustahik menjadi muzakki melalui bantuan modal yang diberikan oleh BAZNAS Tala.

\section{Daftar Pustaka}

A. Qardhawi, Yusuf. 2005. Spektrum Zakat dalam Membangun Ekonomi Kerakyatan. Jakarta: Zikrul.

B. Wulansari. 2014. Analisis peranan dana zakat produktif terhadap perkembangan usaha mikro mustahik (penerima zakat) (studi kasus Rumah Zakat Kota Semarang). Fakultas Ekonomika dan Bisnis. Universitas Diponegoro. Semarang. Skipsi.

C. Alaydrus, M. Zaid (2016). Pengaruh Zakat Produktif terhadap Pertumbuhan Usaha Mikro dan Kesejahteraan Mustahik pada Badan Amil Zakat Kota Pasuruan Jawa Timur. Universitas Airlangga. Surabaya. Tesis.

D. Putri, Gita Anindiya. 2018. Analisis Peran Dana Zakat Produktif terhadap perkembangan Usaha Mikro Mustahik pada Badan Amil Zakat Nasional Sragen. Fakultas Ekonomi dan Bisnis Islam. IAIN. Surakarta. Skripsi.

E. Ghozali, Imam. 2001. Aplikasi SPSS. Semarang: Badan Penerbit Universitas Diponegoro.

F. www.baznastala.or.id. Profil Baznas Tala. Diakses 9 Juli 2019.

G. www.baznastala.or.id. Laporan Keuangan, Laporan Pendistribusian, Baznas Tala Tahuun 2018. Diakses 12 Juli 2019. 